Discussion Paper No. 15-061

Deregulation, Competition, and Consolidation: The Case of the German Interurban Bus Industry

Niklas S. Dürr, Sven Heim, and Kai Hüschelrath

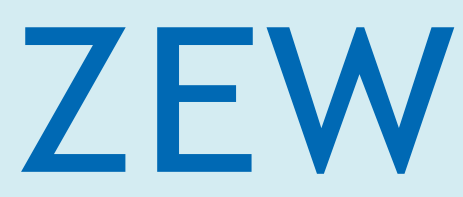

Zentrum für Europäische Wirtschaftsforschung $\mathrm{GmbH}$ Centre for European Economic Research 
Discussion Paper No. 15-061

\section{Deregulation, Competition, and Consolidation: The Case of the German Interurban Bus Industry}

Niklas S. Dürr, Sven Heim, and Kai Hüschelrath

Download this ZEW Discussion Paper from our ftp server:

http://ftp.zew.de/pub/zew-docs/dp/dp15061.pdf

Die Discussion Papers dienen einer möglichst schnellen Verbreitung von neueren Forschungsarbeiten des ZEW. Die Beiträge liegen in alleiniger Verantwortung der Autoren und stellen nicht notwendigerweise die Meinung des ZEW dar.

Discussion Papers are intended to make results of ZEW research promptly available to other economists in order to encourage discussion and suggestions for revisions. The authors are solely responsible for the contents which do not necessarily represent the opinion of the ZEW. 


\title{
DEREGULATION, COMPETITION, AND CONSOLIDATION: THE CASE OF THE GERMAN INTERURBAN BUS INDUSTRY
}

\author{
Niklas S. Dürr*, Sven Heim ${ }^{\dagger}$ and Kai Hüschelrath*
}

August 2015

\begin{abstract}
We provide an empirical assessment of the German interurban bus industry two years after its deregulation in January 2013. In addition to a general description of key developments of the industry, we use a unique route-level price data set to study both competitive interaction in general and the potential price effects of a recently announced merger of the two largest players in the market in particular. We find that route-level average prices, inter alia, do not only depend on the number of competitors but especially on the composition of firms operating on a particular route. Although our empirical results suggest short-term price increases on certain route types post-merger, it remains an open question whether the merger should be classified as anticompetitive.
\end{abstract}

JEL Class L11, L41, L92, K21, K23

Keywords Deregulation, competition, merger, interurban bus services, Germany

* Researcher, Competition and Regulation Research Group, ZEW Centre for European Economic Research, MaCCI Mannheim Centre for Competition and Innovation, Address: P.O. Box 1034 43, D-68034 Mannheim, Germany, E-mail: duerr@zew.de.

† Researcher, Competition and Regulation Research Group, ZEW Centre for European Economic Research, MaCCI Mannheim Centre for Competition and Innovation, Address: P.O. Box 1034 43, D-68034 Mannheim, Germany, E-mail: heim@zew.de.

* Head, Competition and Regulation Research Group, ZEW Centre for European Economic Research, Address: P.O. Box 1034 43, D-68034 Mannheim, Germany, E-mail: hueschelrath@zew.de; Director, MaCCI Mannheim Centre for Competition and Innovation; Professor, University of Mannheim, L7, 3-5, 68131 Mannheim, Germany; Corresponding author; We are indebted to Wolfgang Briglauer, Stefan Frübing, Ulrich Laitenberger, Dominik Schober, Tobias Veith and Oliver Woll for valuable comments and to Victoria Urmetzer for excellent research assistance. The usual disclaimer applies. 


\section{Introduction}

Since the beginning of the deregulation movement in the 1970s in the United States, many regulated industries in a large number of countries have been liberalized ${ }^{1}$ - with so-called network industries being a major focus of such initiatives. By initiating and implementing deregulation processes, policy makers often aimed at increasing allocative and productive efficiency through the promotion of competition and - at the same time - reducing the amounts of subsidies paid to the respective sectors or industries.

From an academic perspective, the transition from regulated to liberalized industries offers a rich set of research questions. Following a methodology by Perl (1997), focal points of interest have been research into the forces that have given rise to regulatory reform or the structures of the respective regulatory changes. The majority of research, however, focuses on the question after the effects of deregulation processes on key market outcome variables such as industry efficiency, prices or profits.

For a few decades, the German interurban bus industry did not follow the described liberalization trends in most network industries in Europe. However, following constant pressures by especially the European Commission, in 2009, the German government announced plans to liberalize the national interurban bus market - defined as regular (scheduled) bus services above a distance of 50 kilometers. After a considerable transition period - in which the respective paragraphs of the Passenger Transportation Act had to be changed - the industry was fully liberalized in January 2013.

Against this background, we provide an empirical assessment of the German interurban bus industry two years after its deregulation. In addition to a general description of key developments of the industry, we use a unique route-level price data set to study both competitive interaction in general and the potential price effects of a recently announced merger of the two largest players in the market - MeinFernbus (MFB) and FlixBus (FB) - in particular. We find that route-level average prices, inter alia, do not only depend on the number of competitors but especially on the composition of firms operating on a particular route. Although our empirical results suggest short-term price increases on certain route types post-merger, it remains an open question whether the merger should be classified as anticompetitive.

1 In the remainder of this article, ‘deregulation' and 'liberalization' are used as synonyms. 
The article is organized as follows. The second section introduces into the German interurban bus industry including a general description of the market and its major players but also a specific discussion of recent first consolidation events. The subsequent third section presents our empirical analysis of price behavior in general and the implications of the recently announced merger between the two largest players in the industry in particular. While Section 3.1 describes the construction of the data set and discusses the descriptive statistics, Section 3.2 continues with the development of our econometric approach and the presentation of our main empirical results. Section 3.3 provides an interpretation of the results and derives several important policy implications. Section 4 concludes the article by summarizing its main results.

\section{The German interurban bus industry}

Although deregulation processes were initiated in many industries and countries in the last two to three decades, a mixture of public policy arguments and lobbying activities delayed the implementation of such processes in several sectors or industries. For Germany, this description applies to the interurban bus industry. Since 1931, bus companies were only allowed to offer regular interurban bus services - above a travel distance of 50 kilometers on routes on which the state-owned German railway company Deutsche Bahn AG (or its predecessors) was unable to provide an acceptable service. Due to the rather dense (interurban) railway network in Germany, the respective law - that aimed at protecting a core business of Deutsche Bahn AG - led to only sporadic interurban bus services except for connections to/from former West Berlin (operated by Berlin Linien Bus) and international connections (by providers such as Eurolines Germany).

The regulation of the German interurban bus industry remained intact until 2009 when the German government announced plans to liberalize the industry (responding to political pressures from the European Union). In the same year, three students established DeinBus.de ${ }^{2}$, a company which, whenever a sufficiently large number of travelers to a certain destination was found, rented a bus and offered the respective service. Additionally, Deutsche Bahn AG started to operate its own busses under the new IC Bus brand around the same time. Despite several attempts by different lobbying groups to prevent or at least weaken any further deregulation of the industry, the German interurban bus industry was fully liberalized

2 See https://www.deinbus.de/ (last accessed on 22 March 2015). 
in January 2013 - after the respective paragraphs of the Passenger Transport Act $^{3}$ were changed in the usual legislative (and lobbying) processes (see generally Maertens (2012) and Schiefelbuch (2013) for further information).

In the remainder of this section, we provide an overview of the deregulated German interurban bus industry. In addition to a general characterization of the industry in Section 2.1., we particularly discuss recently observed first consolidation events (Section 2.2).

\subsection{General characterization of the industry}

Prior experiences with deregulation processes in transport industries in general (see, e.g., Williams (1993), Morrison and Winston (1986, 1995) or Borenstein and Rose (2007) for the US airline industry) and interurban bus industries in particular (see, e.g., Robbins and White (1986, 2012) for Great Britain or Aarhaug et al. (2012) for Norway) would expect - at the early stages of a liberalized industry - substantial market entry by both new and incumbent firms leading either to the creation of new lines and routes or an increase in the number of competitors on existing lines and routes.

The German interurban bus industry appears to follow this general pattern. Following full liberalization in January 2013 many providers decided to apply for an operating license. According to the German Office for Goods Transport (2014, p. 15), the number of licenses increased from 86 in December 2012 to 158 in June 2013 and finally 301 in September 2014 (an overall increase of 350 percent). The increase in licenses is also reflected in an increase in both available lines ${ }^{4}$ and daily frequency of service on these lines. Comparing a week in August 2013 with the same week in August 2014 reveals that the number of lines increased from 113 to 244 (an increase of about 116 percent) while the number of journeys jumped from 2360 to 7088 (an increase of about 300 percent; see German Office for Goods Transport (2014), p. 17).

A key strategy of most new entrants to the industry - such as especially MeinFernbus or FlixBus - to quickly extend their route networks was to avoid buying their own fleet but rather to develop a subcontractor-type business model in which already existing local bus

3 The most important change - leading to the liberalization of the interurban bus industry - referred to §13(2) Personenbeförderungsgesetz ('Passenger Transport Act') in which the strict entry regulations were codified.

4 In the remainder of this article, a line is defined as an offered regular (scheduled) service from a particular departure city to a particular arrival city, e.g., from Hamburg to Munich. A line usually contains several stops, i.e., passengers are able to board the bus at a later city and/or get off the bus at an earlier city than the final destination. We therefore define each combination between two different stops on a line as route, i.e., if a line has $N$ stops, the number of routes is $\sum_{i=1}^{N-1} i$. The route is our unit of observation and analysis in both the descriptive and the econometric approaches. 
companies agree to offer services under the respective (regional or national) interurban bus brand. At least in terms of market share gained, this strategy has proven successful as in August 2014 - on the basis of the number of offered routes - MeinFernbus was the market leader with a share of 29 percent, followed by FlixBus with 24 percent (see German Office for Goods Transport (2014), p. 18) and all remaining operators with substantially smaller market shares - partly because they entered the industry at a later point in time but partly also because they either concentrate on the provision of regional services or operate on a limited selection of lines with a particularly high demand.

Despite the clear growth trend in the German interurban bus industry in the last two years, the overall size of the industry must still be considered as rather small. For example, according to data from the German Federal Statistical Office, 8.2 million passengers travelled (in sum about 2.7 billion passenger kilometers) by regular interurban busses in 2013, compared to about 131 million passengers which travelled on long-distance railway connections in the same year. ${ }^{5}$ According to the most recent traffic forecast conducted by a consortium that was commissioned by the German Federal Ministry of Transport and Digital Infrastructure (2014), a growth to about 25 million passengers (generating in sum about 8.8 billion passenger kilometers) is expected in the German interurban bus industry until the year 2030.

Complementary to the general description of key developments of the German interurban bus industry since deregulation, it adds value to take a closer look at certain key industry characteristics such as especially pricing behavior. In particular, we use our detailed routelevel price data for one week in November 2014 (Tuesday, $11^{\text {th }}$ to Monday, $17^{\text {th }}$ ) - described in detail in Section 3.1 below - to offer several further (descriptive) insights into the industry (see Figure 1).

The upper-left chart in Figure 1 shows the number of (inner German, directional ${ }^{6}$ ) interurban bus routes operated by the largest nine bus companies ${ }^{7}$ in November 2014. It is shown that the

\footnotetext{
Although in sum about 2.6 billion passengers travelled by rail in 2013, the large majority of about 2.5 billion passengers used local trains. As interurban busses by definition operate on medium- and long-haul routes only, it appears more appropriate to relate the 8.2 million bus customers to the 131 million long-distance rail customers. See https://www.destatis.de/DE/ZahlenFakten/Wirtschaftsbereiche/TransportVerkehr/Transport Verkehr.html (last accessed on 22 March 2015) for further information.

6 If a provider operates on a route in both directions, e.g., from Hamburg to Bremen and back to Hamburg - as it is usually the case - we count outward and inward trips as two separate routes as, first, in contrast to, e.g., airlines, bus tickets are typically sold separately for outward and inward journeys. Second, different modes of transport can be used by travelers for outward and inward trips (depending on the individual valuation of time and other trip costs) leading to potentially significant differences in demand (and price).

7 Major players are defined as all companies which offered at least 100 trips on routes within Germany in the observation period in November 2014.
} 
new entrants MeinFernbus (1288 routes), FlixBus (960 routes) and ADAC Postbus (556 routes) have become the by far largest providers on the in sum 1822 routes within Germany leaving the incumbents such as Eurolines Germany (136 routes), DeinBus.de (111 routes), Berlin Linien Bus (111 routes) or IC Bus (18 routes; the latter two owned by Deutsche Bahn AG) with substantially smaller route presences. Interestingly, as all new entrants follow comparable subcontractor-type business models, the respective (firm) sizes - measured here in number of operated routes - can at least partly be explained by the respective times of entry: MeinFernbus entered first in April 2012, followed by FlixBus in February 2013, and ADAC Postbus in October 2013. ${ }^{8}$ Berlin Linien Bus, Eurolines Germany, DeinBus.de and IC Bus were all active before 2013, however, they were constrained substantially in their growth by the existing regulations until January 2013.
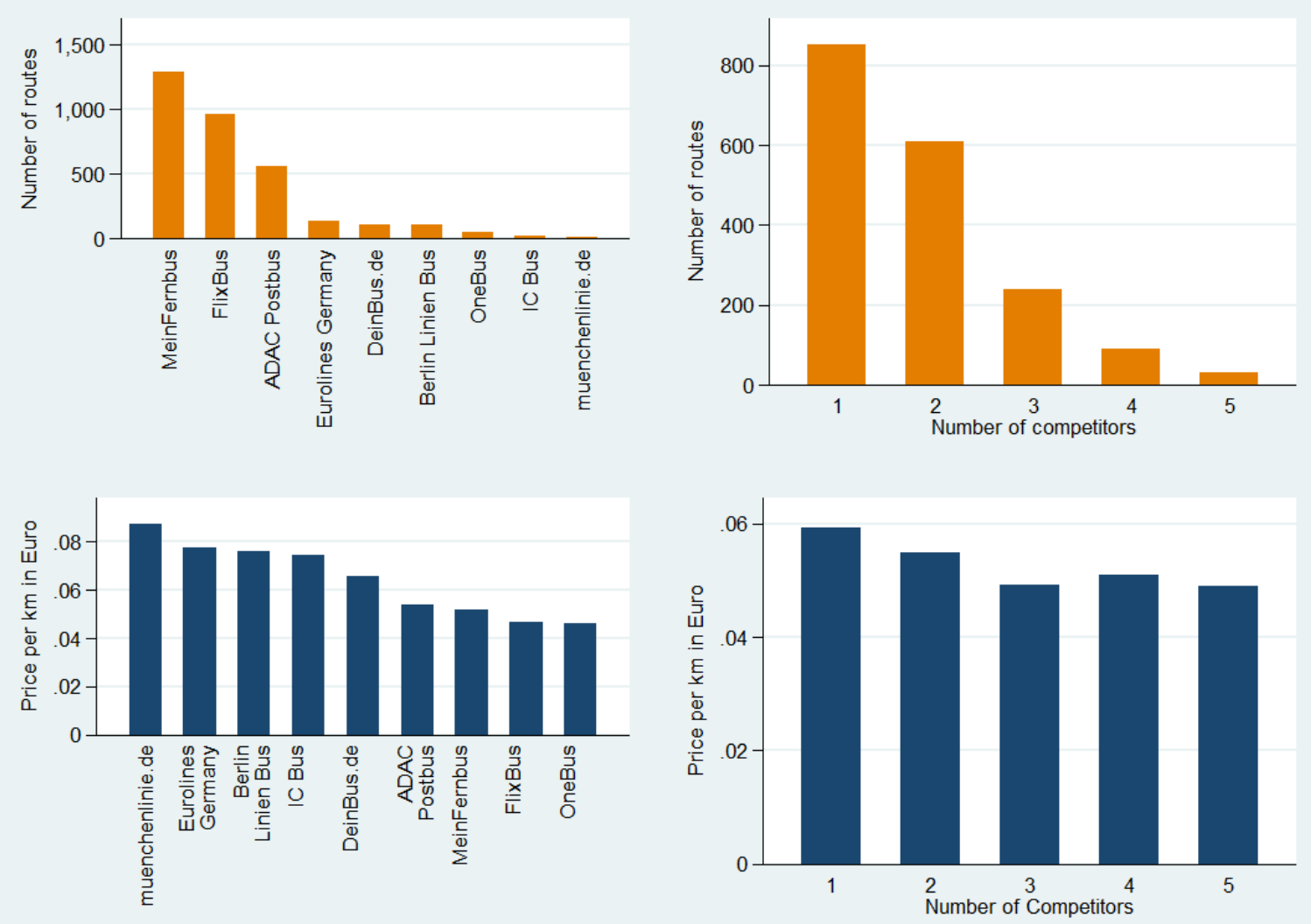

Figure 1: Characteristics of the German interurban bus industry (in November 2014)

Complementary to a snapshot of the number of connections offered, it adds value to characterize the major players further by providing a quick look at their average prices (on a

8 MeinFernbus and FlixBus are both startups (supported by external investors), while ADAC Postbus is run by a consortium of the German automobile club ADAC and the (formerly state-owned but now privatized) German postal service (Deutsche Post AG). In November 2014, ADAC announced to end the consortium contract leaving the German postal service as the sole operator of the service. 
per kilometer basis ${ }^{9}$ ) plotted in the lower-left chart in Figure 1. Although, it is obvious that the calculation of one average price per company hides much information, the chart still reveals substantial between-firm variation. While muenchenlinie.de is the most expensive provider on with a price per kilometer of $0.087 \mathrm{EUR} / \mathrm{km}$, the three largest providers MeinFernbus, FlixBus, and ADAC Postbus offer relatively low average prices. The cheapest provider is DeinBus.de with an average price of $0.046 \mathrm{EUR} / \mathrm{km}$, respectively. Interestingly, the two companies owned by the (state-owned) provider of railway services Deutsche Bahn AG Berlin Linien Bus and IC Bus - are relatively expensive providers with 0.075 EUR/km or $0.076 \mathrm{EUR} / \mathrm{km}$, respectively. As the quality of service appears rather similar between the different providers (as, e.g., most offer services such as free Wi-Fi on board, free luggage, snacks, bike transport, restrooms etc.), the observed differences might reflect different cost structures (e.g., due to different route portfolios and the resulting average travel distances) and/or different pricing strategies (partly driven by brand recognition etc.).

Turning from a simple analysis of average prices per company to a more detailed assessment of the respective price drivers, the number of competitors on the respective routes is an usual suspect. The upper-right chart therefore shows the number of routes that are operated by one, two, three, four or five companies. It is revealed that the majority of 852 routes (out of in sum 1822 routes, i.e. about 47 percent) is operated by only one provider, followed by two providers on 609 routes (about 33 percent), three providers on 241 routes (about 13 percent), four providers on 90 routes (about 5 percent) and the maximum number of five providers on 30 routes (about 1.6 percent). However, despite the fact that the number of monopoly routes is quite large, it is important to add that monopoly markets are typically quite small in terms of overall demand (measured in, e.g., daily frequencies) compared to routes on which a larger number of providers is operating.

The final chart - in the lower-right of Figure 1 - combines the former two charts by breaking down the respective average prices by the number of competitors operating on the respective routes. Supporting main insights of oligopoly theory, average prices are highest (with an average of $0.059 \mathrm{EUR} / \mathrm{km}$ ) if only one provider is operating on the respective route and decrease significantly if a second $(0.055 \mathrm{EUR} / \mathrm{km})$ and third operator $(0.049 \mathrm{EUR} / \mathrm{km})$ is present. A fourth and fifth provider, however, does not have any (larger) additional effect on

9 Although 'price per kilometer' is the standard measure in transport markets, frequent stops (requiring additional kilometers by leaving the highway to reach the respective bus stops in the inner cities) might bias this measure. However, as shown in Dürr and Hüschelrath (2015), descriptive results do not differ to a larger extent between both measures. In our econometric analysis below, we stick to the standard 'price per kilometer' measure, however, control for duration in the regressions. 
average prices in the respective markets. Our empirical analysis below will closer investigate key factors driving these results.

\subsection{Recent consolidation events and their economic assessment}

Following substantial market entry activity by either new or incumbent firms at the early stages of a liberalized industry, it can subsequently be expected that both shrinking growth potentials over time as well as business concepts that turn out to be less successful than others will cause a consolidation phase in which less efficient firms will have to leave the industry either through liquidation or merger.

Despite the fact that the German interurban bus industry was deregulated quite recently, several consolidation events have already been observed. For example, in October 2014, the rather small (but financially powerful) provider City2City - a subsidiary of UK's National Express - went out of business and in November 2014, DeinBus.de entered the state of bankruptcy protection, however, continues to operate for the time being. Very recently and most importantly, in January 2015, the two biggest players in the market - MeinFernbus and FlixBus - announced their plans to merge. Although the small absolute size of the German interurban bus market makes it unlikely that the German Federal Cartel Office will investigate the proposed transaction (basically because the respective worldwide/domestic turnover thresholds set out in merger control are not reached), the announced merger still raises the question after its competitive effects in general and its price effects in particular. This is especially the case as such a merger between the two by far largest providers - in an industry still in its infancy - can certainly have a substantial impact on its future development.

Generally, in order to assess the competitive effects of the announced merger, it is important to analyze not only the number of routes operated by both carriers but especially the degree of overlap between both merging firms prior to the merger and the corresponding (potential) differences in average prices charged and daily frequencies offered (assuming that price and daily frequency are both key competition variables).

However, in addition to an analysis of overlapping markets, a merger between two firms in a network industry can have further implications, particularly as soon as the merger causes an integration of the respective business strategies (see, e.g., Hüschelrath and Müller (2014) for an application to the US airline industry). For example, if one of the two firms had the characteristics of a so-called maverick firm leading to tough (price) competition in the 
respective markets, the merged entity is likely to have incentives to end the respective low price strategy thereby (possibly) harming consumers through price increases.

Furthermore, the merger might generally reduce the power of potential competition in the industry due to the disappearance of a competitor. As a consequence, in addition to an analysis of the consequences of direct competition between both merging partners, their separate roles in pre-merger market competition needs to be assessed as well in order to come to a comprehensive assessment of the potential price effects of a merger.

Again using our route-level data set of one week in November 2014, the initial descriptive analysis of route presence above revealed that MeinFernbus operated on 1288 routes compared to FlixBus with 960 routes. Interestingly, both players competed directly on 691 routes from which they were the only two providers on 348 routes (i.e., a monopoly market will result post-merger). Although a detailed analysis of the implications of this route structure will be provided as part of our empirical assessment in Section 3 below, simple descriptive evidence presented in Figure 2 already offers several further insights on the average daily frequencies and average prices of the merging parties compared to the remaining providers on the respective routes.

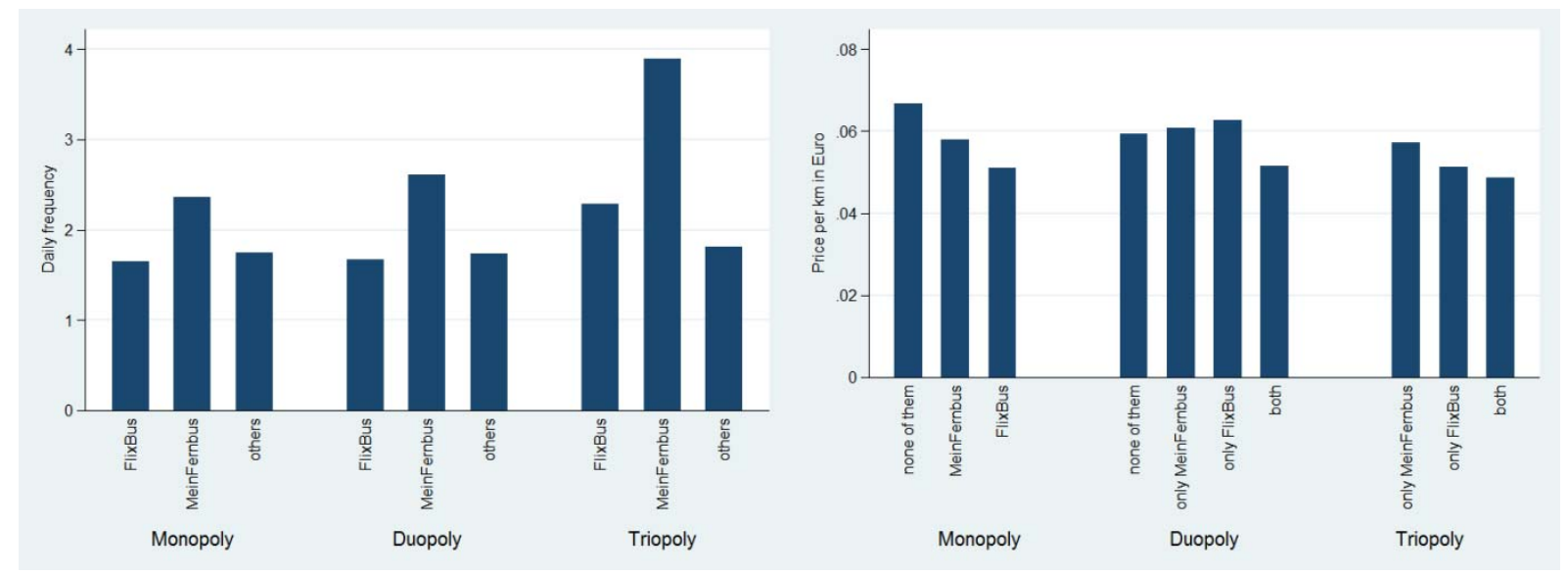

Figure 2: Daily frequencies and average prices of merging parties compared to other large providers (in November 2014)

The left-hand chart in Figure 2 presents the daily frequencies by number of competitors and differentiates between MeinFernbus, FlixBus and other providers. As expected, the average number of daily frequencies increases substantially with the number of competitors. More importantly, the chart reveals that MeinFernbus offers on average much higher daily frequencies than both FlixBus and the other providers. This not only leads to an increase in service quality (as more departures reduce the time span between the desired departure time 
and the actual departure time of the customers) but also promotes the company goal of MeinFernbus to become (or stay, respectively) the leading interurban bus brand in Germany.

Turning from daily frequencies to a second key competition variable in interurban bus markets, namely price, the right-hand chart in Figure 2 on the one hand generally shows the decreasing price trend associated with an increase in the number of competitors (see also Figure 1 above). ${ }^{10}$ Monopoly average prices are found to be highest (with an average of 0.059 EUR/km) if only one provider is operating on the respective route and decrease significantly if a second $(0.055 \mathrm{EUR} / \mathrm{km})$ and third operator $(0.049 \mathrm{EUR} / \mathrm{km})$ is present. However, as also revealed by the chart, the respective averages are hiding substantial between-firm variation as the breakdown between the merging parties and other providers found FlixBus (0.051 EUR $/ \mathrm{km})$ to charge lower monopoly fares than MeinFernbus (0.056 EUR/km). However, the average prices of both firms are clearly below the average prices of the remaining providers operating in the industry $(0.067 \mathrm{EUR} / \mathrm{km})$.

Turning from monopoly to duopoly markets, it is shown that duopolies in which only other providers are operating $(0.059 \mathrm{EUR} / \mathrm{km})$ charge lower prices than FlixBus alone $(0.063$ EUR/km) or MeinFernbus duopolies (0.061 EUR/km). Most importantly, however, routes on which the two merging parties directly compete against each other show the lowest average prices of about $0.051 \mathrm{EUR} / \mathrm{km}^{11}$ thereby suggesting noticeable (at least short-term) prices increases post-merger.

Interestingly, the picture partly changes if triopoly markets are analyzed. Now, FlixBus routes $(0.051 \mathrm{EUR} / \mathrm{km})$ show lower average prices than MeinFernbus triopoly routes $(0.057$ EUR/km) while routes in which both merging parties operate still show an average price below the two former $(0.049 \mathrm{EUR} / \mathrm{km})$. Although these descriptive findings already point towards substantial differences in the pricing strategy of the merging parties, it is obvious that these results must be handled with great care - especially because they do not control for other potential drivers of price differences. In the following section, we will therefore run

10 The absolute numbers of routes in the respective categories are as follows: Monopoly MFB 451 routes, Monopoly FB 159 routes, Monopoly others 242 routes; Duopoly MFB 140 routes, Duopoly FB 98 routes, Duopoly MFB-FB 348 routes, Duopoly others 23 routes; Triopoly MFB 6 routes, Triopoly FB 12 routes, and Triopoly MFB-FB 223 routes.

11 Although these differences, on the surface, appear to be negligible, they are in fact quite substantial. Assuming an average interurban bus trip length of 296.87 kilometers, the customer would face an average price of about $296.87 \mathrm{~km} * 0.061 \mathrm{EUR} / \mathrm{km}=18.10 \mathrm{EUR}$ in markets with presence of FlixBus only, compared to an average price of only $296.87 \mathrm{~km} * 0.051 \mathrm{EUR} / \mathrm{km}=15.14 \mathrm{EUR}$ in markets in which both merging parties are operating (i.e., an about 16.4 percent cheaper price). 
econometric estimations in order to investigate whether our descriptive findings hold in a more sophisticated empirical framework.

\section{Empirical analysis}

In this section, we present an empirical analysis of competitive interaction in the German interurban bus industry in general and study the potential price effects of the recently announced merger between the two largest players in the market - MeinFernbus and FlixBus - in particular. While Section 3.1 describes the construction of the data set and discusses the descriptive statistics of the key variables, Section 3.2 continues with the development of our econometric model and the presentation of our main empirical results. Section 3.3 provides an interpretation of the results and derives several important policy implications.

\subsection{Construction of the data set and descriptive statistics}

The data set used in this article was constructed by merging data from different sources. The basic data set was obtained from http://www.fernbusse.de ${ }^{12}$, one of the leading online search engines for interurban bus travel in Germany for both national and international services. ${ }^{13}$ For all connections, the data set includes information on the date, time and city of origin and destination, duration, provider, included amenities, and price. For our analysis we restricted the data set to, first, connections within Germany and, second, to providers that offered at least 100 trips in the observation period from 11 November 2014 to 17 November 2014. For this week, the data has been queried three times, 14 days, seven days, and one day prior to the respective day of departure. However, as the data (structure) are found not to vary to a larger extent across the three different queries (see Dürr and Hüschelrath (2015) for further information), we only use the data collected seven days before travel in this article. Additionally, we have collected data on Intercity Express (ICE) trains stops, population, share of young people, and income both for the origin and the destination of each connection (obtained from the German Federal Statistical Office). Last but not least, road distances between the respective origin and destination cities were retrieved from Google Maps.

12 See http://www.fernbusse.de (last accessed on 22 March 2015).

13 Although it appears very likely that www.fernbusse.de contains the large majority of bus connections of (at least) all larger providers - justifying the use of the respective data for an analysis of the industry - it remains an open question how good the coverage of the connections available on the site is compared to the overall number of connections available in Germany during the respective observation period. Generally, it is reasonable to assume that competition between these platforms provide strong incentives for the respective operators to maximize the number of connections displayed - under the condition that the platforms operate independently and are not owned (or captured) by one or more providers of the respective bus services. Furthermore, industry studies are typically forced - for practical reasons - to restrict their analysis to firms above a certain size anyway and we therefore do not expect our results to underlie any significant (structural) biases. 
Before we continue with a discussion of the descriptive statistics of the data set, it is important to clearly define our unit of analysis. Generally, three different levels of analysis can be differentiated: the line, the route and the connection (trip). A line is defined as an offered regular (scheduled) service from a particular origin (departure) city to a particular destination (arrival) city, e.g., from Hamburg to Munich. A line usually contains several stops, i.e., passengers are able to board the bus at a later city and/or get off the bus at an earlier city than the final destination. Each combination between two different stops on a line is defined as a route, i.e., if a line has $\mathrm{N}$ stops, the number of routes is $\sum_{i=1}^{N-1} i$. The route is our unit of observation and analysis. In case a provider operates on a route, e.g., from Hamburg to Bremen, in both directions - as it is usually the case - we count outward and inward trips as two separate routes as, first, in contrast to, e.g., airlines, bus tickets are typically sold separately for outward and inward journeys. Second, different modes of transport can be used by travelers for outward and inward trips - depending on the individual valuation of time and other trip costs - leading to potentially significant differences in demand (and price). Last but not least, it is important to remark that for all routes in our data set, we observe the number of connections (trips) per day and week. This information is important to, e.g., analyze the role of daily frequencies of service as important strategic decision variable. In Table 1 we present the descriptive statistics of the key variables of the data set (for bookings seven days before travel).

As revealed by Table 1, the average price for using an interurban bus service was $€ 14.40$ with $€ 4$ and $€ 71$ delineating the spectrum. The average trip had a duration of about 265 minutes and a distance of about 297 kilometers. The average prices per kilometer and per minute show comparable values of 5 or 6 cents, respectively. 74 percent of the origins and destinations had a stop of an ICE train (however not necessarily a direct ICE train connection between the respective origin and destination cities) and the large majority of about 97 percent of all routes were operated by providers following a subcontractor business model. Airport connector routes played a minor role reaching only about 6 percent of all routes. The average route was offered about four times per day (with a rather large spectrum from 1 to $88^{14}$ daily trips) with an average number of about 1.8 providers. The demand-related variables - overall population, share of people aged under 24 years and available income per person - partly reveal substantial variation across cities.

14 The Berlin-Dresden route shows the highest daily frequency of in sum 88 trips. 
Table 1: Descriptive statistics

\begin{tabular}{lccccc}
\hline & \# Obs. & Mean & Std. Dev. & Min. & Max. \\
\hline Price (in $€$ ) & 40,568 & 14.40 & 7.83 & 4 & 71 \\
Duration in minutes & 40,568 & 264.99 & 162.44 & 45 & 970 \\
Distance & 40,568 & 296.87 & 168.59 & 54.50 & 871.00 \\
Price per km & 40,568 & 0.05 & 0.02 & 0.02 & 0.29 \\
Price per minute & 40,568 & 0.06 & 0.02 & 0.02 & 0.25 \\
ICE stops & 40,568 & 0.74 & 0.44 & 0 & 1 \\
Airport connector & 40,568 & 0.06 & 0.23 & 0 & 1 \\
Subcontractor business model & 40,568 & 0.97 & 0.18 & 0 & 1 \\
\hline Daily frequency & 1822 & 4.04 & 5.50 & 1 & 88 \\
Number of providers & 1822 & 1.81 & 0.95 & 1 & 5 \\
\hline Monopoly & 1822 & 0.47 & 0.50 & 0 & 1 \\
Duopoly & 1822 & 0.33 & 0.47 & 0 & 1 \\
Triopoly & 1822 & 0.13 & 0.34 & 0 & 1 \\
\hline Monopoly MeinFernbus & 1822 & 0.25 & 0.43 & 0 & 1 \\
Monopoly FlixBus & 1822 & 0.09 & 0.28 & 0 & 1 \\
Monopoly others & 1822 & 0.13 & 0.34 & 0 & 1 \\
\hdashline Duopoly MeinFernbus & 1822 & 0.08 & 0.27 & 0 & 1 \\
Duopoly FlixBus & 1822 & 0.05 & 0.23 & 0 & 1 \\
Duopoly MeinFernbus + FlixBus & 1822 & 0.19 & 0.39 & 0 & 1 \\
Duopoly others & 1822 & 0.01 & 0.11 & 0 & 1 \\
\hdashline Population ('0000) & 203 & 17.75 & 40.74 & 0.04 & 332.60 \\
Share of under 24 years & 203 & 0.24 & 0.02 & 0.18 & 0.29 \\
Available income ('000 $€$ ) & 203 & 20.24 & 2.45 & 15.78 & 33.34 \\
\hline
\end{tabular}

Additionally, Table 1 also provides some further insights on the degree of competition in the interurban bus industry in general and between the two merging parties in particular. It is shown that about 47 percent of all routes were monopolies with MeinFernbus operating alone on 25 percent of all routes compared to 9 percent in case of FlixBus and 13 percent for all remaining providers. About 33 percent of all routes were operated by two providers with a duopoly of the two merging companies - MeinFernbus and FlixBus - having the by far largest percentage value of about 19 percent, followed by duopolies consisting of MeinFernbus and another provider (about 8 percent) and FlixBus and another provider (about 5 percent). Only about 13 percent of all routes were triopolies leaving about 7 percent of all routes for markets with four or five providers competing for customers. 


\subsection{Modeling approach and empirical results}

Aiming at investigating competitive interaction in the German interurban bus industry in general and the price effects of the announced merger between MeinFernbus and FlixBus in particular, it appears particularly important for the design of the econometric approach to tackle the potential endogeneity problem arising from the simultaneity between the choice of market entry and the expected profits resulting from price setting. As a consequence, in order to allow a causal interpretation of our results, we will follow an instrumental variable approach throughout all our estimations.

The econometric analysis is structured as follows. As starting point we estimate the impact of competition on market prices in general - differentiated further into a model approach including the number of competitors as independent variable and a complementary approach that introduces separate dummy variables for monopoly, duopoly and triopoly routes on the right hand-side of the regression equation. Subsequently, we estimate a refinement of the latter model which allows differentiating between several (route-based) compositions of firms. We generally use the number of competitors (on a certain route) as variable to proxy for the degree of competition (Num_Comp). To control for route-specific supply we additionally include the daily frequency (Daily_Freq) of all providers operating on each route.

In order to receive reliable results, we have to find instruments for both key variables, number of competitors and daily frequency. The instruments we deploy are overall population (Pop), average income (Inc) and share of people aged under 24 (U24) in the origin as well as the destination city. Additional instruments are a dummy variable indicating the availability of ICE rail connections on a route (ICE) and an 'airport connector' indicator variable (Airport). The ICE rail connection and the airport connector variables should, ceteris paribus, reduce demand for interurban busses on such routes, e.g., as the availability of ICE rail connections reduces the attractiveness of the city (for interurban bus connections) or due to a usually large selection of alternative transport modes available at airports (which operate with a substantially higher daily frequency than interurban bus connections). Since demand is a key factor for the attractiveness of entry, it is correlated with the number of competitors. However, we expect multicollinearity problems not to arise as demand is a necessary but not a sufficient condition for entry (as each route can be served by a monopolist). We will report and discuss the respective statistical tests below. 
Following the description above the linear projections in the first stage regressions in the basic model are

(1) Num_Comp $=\delta_{01}+\delta_{11}$ Pop $_{i}+\delta_{21} I_{n c}+\delta_{31} U 24+\delta_{41}$ Airport $_{i}+\delta_{51} I C E_{i}+X_{i}^{\prime} \beta_{2}+\varepsilon_{i 2}$

(2) Daily_Freq $=\delta_{01}+\delta_{11}$ Pop $_{i}+\delta_{21}$ Inc $_{i}+\delta_{31} U 24+\delta_{41}$ Airport $_{i}+\delta_{51} I C E_{i}+X_{i}^{\prime} \beta_{1}+\varepsilon_{i 1}$

The structural equation of our basic model then has the following form:

(3) $\ln$ price $_{i}=\propto_{11}+\propto_{21}$ Num_Comp $_{i}+\alpha_{31}$ Dally_Freq $_{l}+X_{i}^{\prime} \beta_{3}+u_{i 1}$

where the dependent variable is the logarithm of price per kilometer, NuT_Comp and Dal $\widehat{l y \_}$Freq are fitted values from the reduced form and $X$ is a vector of exogenous covariates including distance between city of origin and destination in kilometers $(\mathrm{km})$, squares of distance to allow the impact of distance being non-linear, duration of the time scheduled for a route as well as day of week and daytime dummies.

Although the basic model will, inter alia, provide first insights on the influence of the number of competitors on price, we will run a slightly different approach in which we explore the non-linearities of that impact by replacing the number of providers by dummies for monopoly, duopoly and triopoly markets (with routes having four or five providers acting as reference category). As monopolies mainly exist between smaller cities and triopolies between bigger cities (e.g., compared to the monopoly case the average population in destination cities is $16 \%$ higher for duopolies and even $59 \%$ higher for triopolies) we can use this variation to instrument for the structure of competition in the first stage equations of our empirical model. ${ }^{15}$ Therefore, we construct dummies for bins of the population of origin and destination cities, interact them with the population and deploy them as instruments for monopoly, duopoly and triopoly markets. After experimenting with bins of different sizes we decided to use quintiles due to the best first stage statistics for this specification.

Hence, the structural equation is changed to the following:

(4) $\ln$ price $_{i}=\propto_{12}+a_{22} \widehat{\text { Mono }}_{l}+\alpha_{32} \widehat{\text { Duo }}_{l}+\propto_{42} \widehat{\text { Trlo }}_{l}+\propto_{52}$ Dally_Freq $_{l}+X_{i}^{\prime} \beta_{4}+u_{i 2}$

Based on the two specifications of our basic structural equation, Table 2 presents our regression results.

15 Information on variation of the respective variables is provided in Table 5 in the Annex. 
Table 2: General price determinants IV estimation results (November 2014)

\begin{tabular}{|c|c|c|c|c|}
\hline & $\begin{array}{c}\text { (1) } \\
\text { Price per km }\end{array}$ & $\begin{array}{c}(2) \\
\text { Price per km }\end{array}$ & $\begin{array}{c}\text { (3) } \\
\text { Price per km }\end{array}$ & $\begin{array}{c}\text { (4) } \\
\text { Price per km }\end{array}$ \\
\hline Number of providers on relation & $\begin{array}{l}-0.0584^{* * *} \\
(0.00338)\end{array}$ & $\begin{array}{l}-0.0557^{* * *} \\
(0.00324)\end{array}$ & & \\
\hline Monopoly & & & $\begin{array}{l}0.220^{* * *} \\
(0.0152)\end{array}$ & $\begin{array}{l}0.228^{* * *} \\
(0.0147)\end{array}$ \\
\hline Duopoly & & & $\begin{array}{l}0.116^{* * *} \\
(0.0105)\end{array}$ & $\begin{array}{l}0.103^{* * *} \\
(0.0101)\end{array}$ \\
\hline Triopoly & & & $\begin{array}{r}0.00899 \\
(0.0112) \\
\end{array}$ & $\begin{array}{c}0.0164 \\
(0.0107) \\
\end{array}$ \\
\hline Daily frequency & $\begin{array}{l}-0.00182^{* * * *} \\
(0.000283)\end{array}$ & $\begin{array}{l}-0.00197^{* * *} \\
(0.000272)\end{array}$ & $\begin{array}{l}-0.00215^{* * *} \\
(0.000291)\end{array}$ & $\begin{array}{l}-0.00232^{* * *} \\
(0.000281)\end{array}$ \\
\hline Distance in km & $\begin{array}{l}-0.00240^{* * *} \\
(0.0000421)\end{array}$ & $\begin{array}{l}-0.00247^{* * *} \\
(0.0000406)\end{array}$ & $\begin{array}{l}-0.00232^{* * *} \\
(0.0000432)\end{array}$ & $\begin{array}{l}-0.00239^{* * *} \\
(0.0000419)\end{array}$ \\
\hline Distance in km squared & $\begin{array}{c}0.00000132^{* * * *} \\
(4.00 \mathrm{e}-08)\end{array}$ & $\begin{array}{c}0.00000137^{* * *} \\
(3.91 \mathrm{e}-08)\end{array}$ & $\begin{array}{c}0.00000129^{* * *} \\
(4.17 \mathrm{e}-08)\end{array}$ & $\begin{array}{c}0.00000135^{*+*} \\
(4.09 \mathrm{e}-08)\end{array}$ \\
\hline Duration in minutes & $\begin{array}{l}0.000706^{* * *} \\
(0.0000277)\end{array}$ & $\begin{array}{l}0.000752^{* * *} \\
(0.0000262)\end{array}$ & $\begin{array}{l}0.000666^{* * *} \\
(0.0000293)\end{array}$ & $\begin{array}{l}0.000699^{* * *} \\
(0.0000279)\end{array}$ \\
\hline Wednesday & & $\begin{array}{l}0.000829 \\
(0.00504)\end{array}$ & & $\begin{array}{c}0.00138 \\
(0.00505)\end{array}$ \\
\hline Thursday & & $\begin{array}{c}0.00746 \\
(0.00473)\end{array}$ & & $\begin{array}{c}0.00821 \\
(0.00475)\end{array}$ \\
\hline Friday & & $\begin{array}{c}0.138^{* * *} \\
(0.00479)\end{array}$ & & $\begin{array}{c}0.137^{* * *} \\
(0.00482)\end{array}$ \\
\hline Saturday & & $\begin{array}{l}0.0160^{* * *} \\
(0.00478)\end{array}$ & & $\begin{array}{l}0.0172^{* * * *} \\
(0.00481)\end{array}$ \\
\hline Sunday & & $\begin{array}{c}0.200^{* * *} \\
(0.00517)\end{array}$ & & $\begin{array}{c}0.200^{* * * *} \\
(0.00520)\end{array}$ \\
\hline Monday & & $\begin{array}{c}0.00399 \\
(0.00470)\end{array}$ & & $\begin{array}{c}0.00389 \\
(0.00472)\end{array}$ \\
\hline Morning (6am - 12am) & & $\begin{array}{l}-0.0563^{* * *} \\
(0.00797)\end{array}$ & & $\begin{array}{l}-0.0618^{* * *} \\
(0.00812)\end{array}$ \\
\hline Afternoon (12am - 6pm) & & $\begin{array}{l}-0.0159^{*} \\
(0.00802)\end{array}$ & & $\begin{array}{l}-0.0229^{* *} \\
(0.00817)\end{array}$ \\
\hline Evening $(6 \mathrm{pm}-12 \mathrm{pm})$ & & $\begin{array}{l}-0.0394^{* * *} \\
(0.00843)\end{array}$ & & $\begin{array}{l}-0.0454^{* * *} \\
(0.00859)\end{array}$ \\
\hline Constant & $\begin{array}{l}-2.438^{* * *} \\
(0.00743)\end{array}$ & $\begin{array}{l}-2.464^{* * *} \\
(0.0115)\end{array}$ & $\begin{array}{l}-2.674^{* * *} \\
(0.0118)\end{array}$ & $\begin{array}{l}-2.684^{* * * *} \\
(0.0135)\end{array}$ \\
\hline Angrist-Pischke first stage F-Test (Freq.) & 287.54 & 293.73 & 289.42 & 294.78 \\
\hline Angrist-Pischke first stage F-Test (\# Comp.) & 337.17 & 332.17 & & \\
\hline Angrist-Pischke first stage F-Test (Mono.) & & & 142.03 & 141.08 \\
\hline Angrist-Pischke first stage F-Test (Duo.) & & & 247.41 & 244.13 \\
\hline Angrist-Pischke first stage F-Test (Trio.) & & & 153.44 & 153.45 \\
\hline Kleibergen-Paap Wald rk F-Statistic & 341.86 & 341.63 & 109.57 & 109.19 \\
\hline Test of endogeneity & 0.0000 & 0.0000 & 0.0000 & 0.0000 \\
\hline Stock-Yogo weak ID test critical values (10\%) & 11.41 & 11.41 & 11.44 & 11.44 \\
\hline \# of observations & 40.568 & 40.568 & 40.568 & 40.568 \\
\hline
\end{tabular}

As the respective estimation results shown in columns (1) and (2) in Table 2 differ only slightly, we concentrate our discussion on the richer second specification. As expected, it is found that average prices decrease for an increasing number of providers on a certain route. On average, prices decrease by about 5.6 percent for every additional provider on a particular 
route. We additionally find daily frequency to have a small but negative effect on the average price likely indicating the cost decreasing effect from (scale) economies. Furthermore, while duration is found to have a positive impact on price, the opposite is true for distance (likely reflecting economies of distance that might occur as soon as either (trip-specific) fixed costs are shared over a longer trip or certain cost components increase at a lower rate with an increase in trip length). As the coefficients shown in Table 2 cannot be interpreted in a straightforward way, Figure 3 below plots $\ln$ (price per kilometer) against kilometer clearly showing the expected price degression effect with increasing travel distance (see Dürr and Hüschelrath (2015) for further discussions on the relationship between average price and haul).

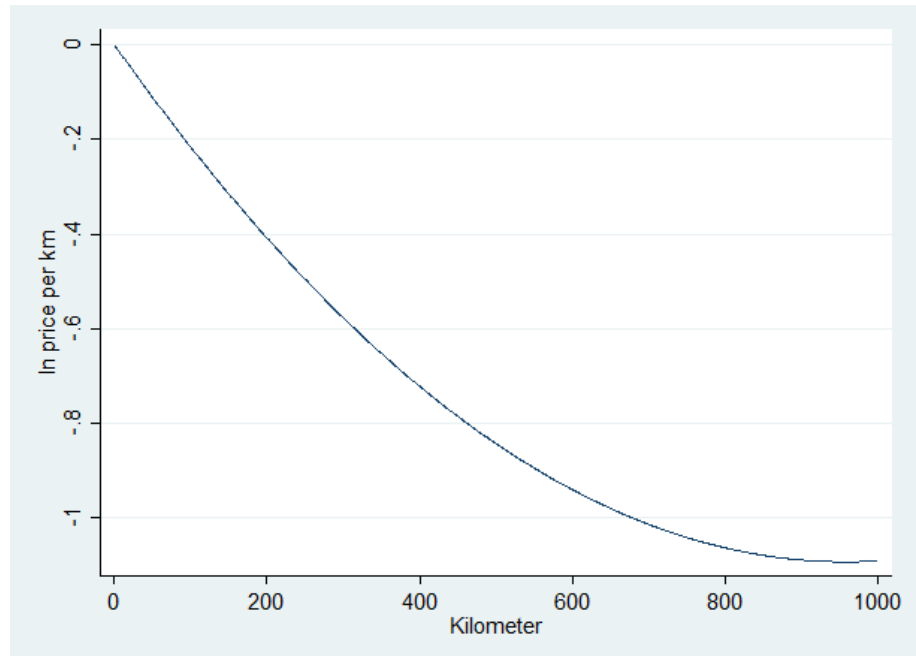

Figure 3: Price degression effect with respect to distance (referring to (2) in Table 2)

Additionally, column (2) in Table 2 shows further that especially Friday and Sunday have significantly higher prices (about 13.8 percent or 20.0 percent, respectively) than the other days of the week. In terms of time of travel, day trips are found to be (on average) between 1.6 percent (afternoon) and 5.6 percent (morning) cheaper than night trips.

Furthermore, from a technical perspective, we expected that multicollinearity problems do not arise as demand is a necessary but not sufficient condition for entry. ${ }^{16}$ Confirming this conjecture, we find that both endogenous variables are identified by the instruments as indicated by the Angrist-Pischke First Stage F-Test which clearly exceeds the IV critical value by Stock and Yogo (2005). Furthermore, the equation is identified as a whole as shown by the high Kleibergen Paap rk Wald F-statistic reported in Table 2 above. Additionally, the Durbin-

16 The correlation between the 'Daily frequency' and 'Number of competitors' variables on a route is 0.5577. 
Wu Hausman test rejects the null hypothesis of daily frequency of operating services and competition being exogenous variables for all models. Hence, the estimation method is IVGMM and, since there is some heterogeneity in the error term, a robust covariance matrix estimator is applied. ${ }^{17}$

Columns (3) and (4) in Table 2 replace the 'number of providers' variable with separate dummies for monopoly, duopoly and triopoly routes (and routes with four or five providers acting as reference category). Most interestingly, we find that monopoly routes have about 22.8 percent higher prices and duopoly routes about 10.3 percent higher prices than on the routes with four or five competitors. However, the results also show that fares charged on triopoly routes are not statistically different from the fares charged on the routes in the reference group (supporting the descriptive findings shown in Figure 1 above). Although this finding contradicts with the expectation of oligopoly theory, the difference is not substantial and might be driven by certain routes in the sample (especially as the absolute number of routes is rather small as shown in Figure 1 above).

In addition to a general analysis of price determinants in the German interurban bus market, we specifically aim at investigating the behavior of the two market leaders - and at the same time merging parties - in greater detail. Consequently, we start from equation (3) above and add dummy variables for, first, monopoly routes which are either served by MeinFernbus (Mono_MFB) or by Flixbus (Mono_FB) or by neither of them (Mono_others), and, second, duopoly routes which are either operated by a duopoly consisting of both MeinFernbus and FlixBus (Duo_MFB_FB) or which are served by a duopoly with only one of the merging parties (Duo_MFB or Duo_FB) ${ }^{18}$ In order to make the different monopoly and duopoly estimates comparable to the reference group of all routes with more than two providers, we exclude duopolies from the monopoly estimation and monopolies from the duopoly estimation. The significant variation in the population of origin and destination cities for monopoly as well as duopoly constellations (see Table 5 in the Annex) again allows us to use quantiles of the population in the respective cities as instruments. For monopolies the endogenous variables are best identified by terciles while for duopolies quintiles yield the best first stage identification of the estimated parameters.

17 For reasons of completeness, we also report the results of simple OLS regressions in Table 6 in the Annex.

18 We do not include a dummy variable for duopoly routes which are served by neither of the two merging parties since these only sum up to about 1 percent of all routes in our data set. 
The structural equations of the two models just described have the following functional form:

$$
\begin{aligned}
& \ln \text { price }_{i}=\alpha_{13}+\alpha_{23} \text { Mono_MF } B_{i}+\alpha_{33} \text { Mono_F } B_{i}+\alpha_{43} \text { Mono_other } s_{i}+ \\
& \propto_{53}{\text { Dal } \widehat{y_{-} F} \text { req }}_{i}+X_{i}^{\prime} \beta_{5}+u_{i 3} \\
& \ln \text { price }_{i}=\alpha_{14}+\alpha_{24} \text { Du } \widehat{u \_M} F B_{i}+\alpha_{34} D \widehat{\text { uo_F }} B_{i}+ \\
& \alpha_{44} \text { Duo_ } \overline{M F B} B_{-} F B_{i} \propto_{54} \text { Dal } \widehat{y_{-} F} r e q_{\imath}+X_{i}^{\prime} \beta_{6}+u_{i 4}
\end{aligned}
$$

Table 3 below shows the results of the respective estimations with columns (1) and (2) introducing the three monopoly dummies (including and excluding calendar controls) and columns (3) and (4) showing the same type of results for duopoly markets. ${ }^{19}$ The control variables mentioned in the discussion of Table 2 above are included but not reported.

Starting off with the monopoly routes (presented in columns (1) and (2)), results for the regressions with or without calendar controls do not differ much in terms of the size of the coefficients. Monopolies operated by MeinFernbus are about 16.0 percent (or 15.9 percent, respectively) more expensive than the routes in the reference group while the monopolies by other providers are found to charge price premiums of on average 30.0 percent (30.0 percent). Furthermore, fares charged in FlixBus monopolies are not statistically significant from the fares charged on the routes in the reference category, i.e., on monopoly routes, FlixBus is the by far cheapest provider thereby confirming our descriptive finding in Figure 2 above.

Even more importantly, columns (3) and (4) in Table 3 presents the respective estimation results for the duopoly routes. Again, the results only slightly depend on the decision whether or not to include calendar controls on the right-and side of the estimation equation. For both specifications, we find substantial price premiums on routes on which either MeinFernbus (35.8 percent or 37.1 percent, respectively) or FlixBus (31.1 percent or 34.6 percent, respectively) are operating. However, most interestingly, if MeinFernbus and FlixBus directly compete against each other on duopoly routes, average prices are only about 8.0 percent or 8.9 percent, respectively, higher than on the (more competitive) routes in the reference group. These results therefore clearly suggest that direct competition between the two merging parties is of value to consumers as its leads to lower average prices than in other constellations of duopoly competition.

19 Again, the instruments are found to be relevant as indicated by the first stage test statistics in Table 3 ruling out weak identification as a potential issue. Although Stock and Yogo (2005) IV critical values are only calculated for up to three endogenous regressors, the rule by thumb critical value of 10 - in the sense of Staiger and Yogo (1997) - can be applied. 
Table 3: Specific price determinants IV estimation results (November 2014)

\begin{tabular}{|c|c|c|c|c|}
\hline & $\begin{array}{c}\text { (1) } \\
\text { Price per km }\end{array}$ & $\begin{array}{c}\text { (2) } \\
\text { Price per km }\end{array}$ & $\begin{array}{c}\text { (3) } \\
\text { Price per km }\end{array}$ & $\begin{array}{c}\text { (4) } \\
\text { Price per km }\end{array}$ \\
\hline Monopoly MeinFernbus & $\begin{array}{l}0.159^{* * *} \\
(0.011)\end{array}$ & $\begin{array}{l}0.160^{* * *} \\
(0.011)\end{array}$ & & \\
\hline Monopoly FlixBus & $\begin{array}{l}-0.008 \\
(0.080)\end{array}$ & $\begin{array}{l}-0.031 \\
(0.078)\end{array}$ & & \\
\hline Monopoly others & $\begin{array}{l}0.300^{* * *} \\
(0.054)\end{array}$ & $\begin{array}{l}0.300^{* * *} \\
(0.052)\end{array}$ & & \\
\hline Duopoly MeinFernbus & & & $\begin{array}{l}0.371^{* * *} \\
(0.029)\end{array}$ & $\begin{array}{l}0.358^{* * *} \\
(0.027)\end{array}$ \\
\hline Duopoly FlixBus & & & $\begin{array}{l}0.346^{* * *} \\
(0.031)\end{array}$ & $\begin{array}{l}0.311^{* * *} \\
(0.029)\end{array}$ \\
\hline Duopoly MeinFernbus + FlixBus & & & $\begin{array}{l}0.089^{* * *} \\
(0.010)\end{array}$ & $\begin{array}{l}0.080^{* * *} \\
(0.009)\end{array}$ \\
\hline Daily frequency & $\begin{array}{l}-0.003^{* * *} \\
(0.000) \\
\end{array}$ & $\begin{array}{l}-0.003^{* * *} \\
(0.000) \\
\end{array}$ & $\begin{array}{l}-0.001^{* * *} \\
(0.000) \\
\end{array}$ & $\begin{array}{c}-0.002^{* * *} \\
(0.000)\end{array}$ \\
\hline Calendar controls & no & yes & no & yes \\
\hline Angrist-Pischke first stage F-Test (1) & 348.67 & 350.67 & 62.12 & 62.09 \\
\hline Angrist-Pischke first stage F-Test (2) & 23.14 & 22.98 & 49.19 & 49.37 \\
\hline Angrist-Pischke first stage F-Test (3) & 35.63 & 35.06 & 310.35 & 307.92 \\
\hline $\begin{array}{l}\text { Angrist-Pischke first stage F-Test } \\
\text { (Freq.) }\end{array}$ & 520.66 & 532.07 & 296.33 & 302.09 \\
\hline Kleibergen-Paap Wald rk F-Statistic & 17.77 & 17.65 & 51.48 & 51.87 \\
\hline $\begin{array}{l}\text { Stock-Yogo weak ID test critical } \\
\text { values }(10 \%)\end{array}$ & 11.52 & 11.52 & 11.44 & 11.44 \\
\hline $\begin{array}{l}\text { Test of endogeneity } \\
\text { \# of observations }\end{array}$ & $\begin{array}{l}0.0000 \\
28,688\end{array}$ & $\begin{array}{l}0.0000 \\
28,688\end{array}$ & $\begin{array}{l}0.0000 \\
34,959\end{array}$ & $\begin{array}{l}0.0000 \\
34,959\end{array}$ \\
\hline
\end{tabular}

Notes: Robust standard errors in parentheses; 2-step GMM estimation is applied; All variables reported above are treated as endogenous; Instruments are terciles and quintiles, respectively, of population, fraction of people aged under 24 and available income plus dummies for airport connector and ICE rail connections in origin and destination cities; Not reported (though included) are the control variables shown in Table 2; Significance level: ${ }^{*} p<0.1,{ }^{* *} p<0.05,{ }^{* * *} p<0.01$.

Although it certainly would have been desirable to conduct the same type of analysis for triopoly routes as well, the small sample of routes in general and the impossibility to construct a suitable reference category in particular did not allow us to run comparable regressions for this route category.

\subsection{Interpretation of results and policy implications}

Our empirical results presented in the preceding section certainly demand a closer interpretation and discussion of policy conclusions. However, before we continue, it is important to recall the limitations of our empirical analysis, in particular, the restriction of our data set to one week in November 2014. Although this week was chosen for no particular reason, it cannot be ruled out that, e.g., seasonal effects and/or other demand- or supply shocks might bias our results. Nevertheless, we believe that our empirical analysis provides important first insights on the inner workings of a recently liberalized industry. 
Furthermore, in order to be able to provide some robustness check of especially the (potentially more sensitive) results of our merger assessment, we have collected a full data set for an additional week in January 2015 (17 January to 23 January 2015). Although the merger plans of MeinFernbus and FlixBus became public on 7 January 2015, our data again refers to bookings seven days in advance therefore making a direct (substantial) impact of the merger plans unlikely. The results of running identical regressions for the new data set - that contains more observations due to a general increase in both daily frequencies and number of operated routes - are presented in Table 7 in the Annex. In order to ease a comparison of the key results between November 2014 and January 2015, we contrast the respective price premiums (compared to oligopoly routes) in Table 4 below.

Table 4: Comparison of price premiums (compared to oligopoly routes)

\begin{tabular}{|c|c|c|c|c|}
\hline & \multicolumn{2}{|c|}{ November 2014} & \multicolumn{2}{|c|}{ January 2015} \\
\hline & Price per km & Price per km & Price per km & Price per km \\
\hline & & Including & & Including \\
\hline & & Calendar & & Calendar \\
\hline & & Controls & & Controls \\
\hline & $(1)$ & $(2)$ & $(3)$ & $(4)$ \\
\hline \multicolumn{5}{|l|}{ Monopoly routes } \\
\hline Monopoly MeinFernbus & $15.9 \%$ & $16.0 \%$ & $16.2 \%$ & $16.6 \%$ \\
\hline Monopoly FlixBus & $-0.8 \%$ & $-3.1 \%$ & $36.4 \%{ }^{* * *}$ & $37.4 \%{ }^{* * *}$ \\
\hline Monopoly others & $30.0 \%{ }^{* * *}$ & $30.0 \%{ }^{* * *}$ & $22.3 \%{ }^{* * *}$ & $22.7 \%{ }^{* * *}$ \\
\hline \multicolumn{5}{|l|}{ Duopoly routes } \\
\hline Duopoly MeinFernbus & $37.1 \%$ & $35.8 \%$ & $42.9 \%$ & $44.6 \%$ \\
\hline Duopoly FlixBus & $34.6 \%{ }^{* * *}$ & $31.1 \%^{* * *}$ & $40.8 \%{ }^{* * *}$ & $40.7 \%^{* * *}$ \\
\hline Duopoly MeinFernbus + FlixBus & $8.9 \%{ }^{* * *}$ & $8.0 \%{ }^{* * *}$ & $5.0 \%{ }^{* * *}$ & $5.2 \%{ }^{* * *}$ \\
\hline
\end{tabular}

Significance level: ${ }^{*} p<0.1,{ }^{* *} p<0.05,{ }^{* * *} p<0.01$

As shown in Table 4, although the coefficients partly differ with respect to their size, their direction and significance largely remain uncharged when comparing November and January results. The only notable difference occurs with respect to monopoly routes of FlixBus which - in November - were found to have no significant price premium. For January, however, we find results - much more in line with the results of MeinFernbus monopolies - showing (highly significant) price premiums of 36.4 percent (excluding calendar controls) and 37.4 percent (including calendar controls). Furthermore, our November results for the duopoly routes are largely confirmed by the respective regressions for January. This is especially true for the clear price-decreasing effect of a direct confrontation of MeinFernbus and FlixBus in duopoly markets. 
Turning to an interpretation of the results of our econometric approach, we can generally say that our evidence supports the hypothesis that competition in the German interurban bus industry is workable (and working). After liberalization, frequent firm and route entries have been observed leading to a quick extension of the respective route networks. In terms of price determinants, our general price regressions led to results largely in accordance with basic microeconomic/oligopoly theory, namely that average prices decrease with distance and the number of providers on the respective route. Furthermore, price setting responds to weekly demand changes (i.e., prices are significantly higher on Friday and Sunday) and cost changes (i.e., prices are significantly higher for night trips).

From a more specific perspective, our results also provide a closer look into the pricing behavior of selected firms, in particular the two market leaders (and merging parties) MeinFernbus and FlixBus. While on its monopoly routes, FlixBus is charging substantially lower price premiums than MeinFernbus in November 2014 (compared to the reference group of routes with three or more competitors), the effect is reversed for January 2015. For duopoly routes with presence of one of the two, however, we find very comparable price premiums (of about 40 percent). However, if both companies compete directly in a duopoly market, the price premium is reduced substantially to values between 5.0 percent and 8.9 percent, respectively. This finding suggests that direct competition between the two leading players in the industry is of particular value for the consumers in the sense that it is likely to lead to lower prices.

However, what appears to be a puzzling result is the fact that the price premiums of the merging parties in monopoly markets tend to be lower than the price premiums for duopoly routes. Although this finding might be driven by the specificities of respective portfolios of monopoly routes (that all belong to certain lines of the respective providers), an alternative explanation would be a limit pricing strategy followed by the respective providers of the monopoly services. Such a strategy would sacrifice a (substantial) share of the price premium in order to discourage entry by other providers.

What are the implications of these findings for the recently announced merger between MeinFernbus and FlixBus? Taking the route network of November 2014 as given, the merger would end direct competition on 348 duopoly routes (and reduce competition on 223 triopoly 
routes $^{20}$ as well) suggesting price increases for the respective customers traveling on these routes. However, whether these price increases will actually materialize post-merger will very much depend on the pricing strategy of the merged entity. If the FlixBus or MeinFernbus monopoly pricing strategies (in November 2014) are followed, price decreases could even be expected. However, as argued above, current specificities of monopoly route portfolios might drive these results (which surely are affected by the implementation of the announced merger). Furthermore, the pricing strategy of the merged entity is also important for the respective (pre-merger) monopoly routes (although our analysis of the two cross-sections admittedly show contradictory results). Generally, it would therefore be crucial to gain additional knowledge on the motivations behind the observed pricing strategies, e.g., through a field study with the merging parties, in order to assess the likely pricing behavior postmerger. Although our results do find certain differences in the pricing strategies of the two merging parties, they do not allow the conclusion that particularly the smaller provider FlixBus must be classified as maverick firm that potentially deserves special protection by antitrust policy in order to maintain competition in the industry.

More generally, although our empirical results suggest (at least short-term) post-merger price increases for several groups of customers, for a number of reasons, this does not allow the immediate conclusion that the merger should be classified as anticompetitive. First, from an antitrust perspective, it remains unclear whether the German interurban bus market constitutes an own relevant market or must be considered as a (rather small) fraction of a much larger transportation market (possibly including car sharing agencies, railway services etc.). While the narrow delineation of the relevant market would (by construction) lead to high market shares and therefore competition concerns, the latter broader delineation is likely to result in the conclusion that anticompetitive effects are unlikely to exist. In this respect, it should also be taken into account that the demand for interurban bus travel must be considered as highly elastic and market entry barriers as rather low (thereby reducing the possibilities to abuse market power through the implementation of permanent price increases).

Second, although our empirical results suggest short-term price increases on certain route types post-merger, realized merger efficiencies might (partly) be passed-on to consumers through price reductions in the medium and long run. Furthermore, other providers of bus services might specifically enter markets in which market power has increased post-merger

${ }^{20}$ The impossibility to construct a reliable (i.e., sufficiently large) reference group foreclosed the inclusion of this route category into our econometric analysis. 
(and positive profits can be earned). Both potential effects - realized merger efficiencies and possible supply-side reactions to post-merger increases in market power - must be assessed in greater detail before a well-founded conclusion on the overall competitive effects of the announced merger can be drawn.

Last but not least, it has been argued by industry experts (see, e.g., German Office for Goods Transport (2014)) that the current price levels in the industry do not allow making permanent positive profits. It is therefore partly believed that industry consolidation and a corresponding reduction in competitive pressures, e.g., through the proposed merger, is necessary to reach a sustainable long-term industry equilibrium. Due to the absence of detailed (firm-level) cost (and profit) data, we are unable to investigate the correctness (and relevance) of this argument any further.

\section{Conclusions}

In this article, we have provided an empirical assessment of the German interurban bus industry two years after its deregulation. In addition to a general description of key developments of the industry, we have used a unique route-level price data set to study both competitive interaction in general and the potential price effects of a recently announced merger of the two largest players in the market in particular. We found that route-level average prices, inter alia, do not only depend on the number of competitors but especially on the composition of firms operating on a particular route.

Although our empirical results suggest short-term price increases on certain route types as a consequence of the recently announced merger between the two industry leaders MeinFernbus and FlixBus, a much more detailed analysis of the relevant antitrust market, possible demandand/or supply-side merger efficiencies or the cost structure of the industry would be necessary to come to reliable answers to the question whether the merger should be classified as anticompetitive. Future research on the basis of richer panel data sets would not only allow to shed further light on some of these important open question but would also mitigate possible data-related issues that are generally attached to statistical analyses of cross sections.

From a broader policy perspective, it appears particularly important for the future development of the industry to assure that potential barriers to market entry in general and route entry in particular remain low. Taking experiences from other network industries into account, especially the access to existing infrastructure components - first and foremost the bus stations in the respective cities but also, e.g., feeder roads from the city centres to the 
highways (and vice versa) - must be granted on a transparent and non-discriminatory basis. Complementary, the extension of such infrastructure components must be considered as well - as soon as capacity limits become binding for a sufficiently large fraction of the day, the week, the month or the year - in order to be able to realize further growth potentials and to keep interurban bus markets open for market entry and competition. Such competition is not only likely to discipline pricing behavior in the interurban bus industry itself but will also create important knock-on effects on the pricing behavior in adjacent industries - such as railways or car sharing agencies - which are likely to directly compete for the same group of (price-sensitive) customers.

\section{References}

Aarhaug, J., N. Fearnley and P. Christiansen (2012), Deregulation of a Long Distance Express Coach Market, Working Paper, Institute of Transport Economics, Oslo.

Borenstein, S. and N. Rose (2007), How Airline Markets Work ... Or Do They? Regulatory Reform in the Airline Industry, NBER Working Paper 13452, Cambridge.

Dürr, N. and K. Hüschelrath (2015), Competition in the German Interurban Bus Industry - A Snapshot Two Years After Liberalization, Unpublished Working Paper, Mannheim.

Federal Ministry of Transport and Digital Infrastructure (2014), Verkehrsprognose 2030, Anlage Verkehrsverflechtungsprognose, June 2014, Berlin.

Maertens, S. (2012), Buslinienfernverkehr in Deutschland - effiziente Ausgestaltung einer Liberalisierung, Wirtschaftsdienst 2012-8, 554-562.

Morrison, S. and C. Winston (1995), The Evolution of the Airline Industry, Washington D.C.

Morrison, S. and C. Winston (1986), The Economic Effects of Airline Deregulation, Washington D.C.

Office for Goods Transport (2014), Marktbeobachtung Güterverkehr - Marktanalyse des Fernbuslinienverkehrs 2014, Köln.

Perl, L. (1997), Regulatory Restructuring in the United States, Utilities Policy 6, 21-34.

Robbins, D. and P. White (2012), Long-term Development of Express Coach Services in Britain, Research in Transport Economics 36, 30-38.

Robbins, D. and P. White (1986), The Experience of Express Coach Deregulation in Great Britain, Transportation 13, 359-384.

Schiefelbusch, M. (2013), Past and Future Regulation of Interurban Coach Services in Germany, Journal of Transport Economics and Policy 47, 299-305.

Staiger, D. and J. Stock (1997), Instrumental Variables Regression with Weak Instruments, Econometrica 65, 557-586. 
Stock, J. and M. Yogo (2005), Testing for weak instruments in linear IV regression, in: Identification and Inference for Econometric Models: Essays in Honor of Thomas Rothenberg, Chap. 5, 80-108.

Williams, G. (1993), The Airline Industry and the Impact of Deregulation, Cambridge. 


\section{Annex}

\section{Table 5: Variation of selected variables (November 2014)}

\begin{tabular}{lcccccc}
\hline & $\begin{array}{c}\text { Population } \\
\text { origin }\end{array}$ & $\begin{array}{c}\text { Population } \\
\text { destination }\end{array}$ & $\begin{array}{c}\text { Under 24 } \\
\text { years origin }\end{array}$ & $\begin{array}{c}\text { Under 24 } \\
\text { years } \\
\text { destination }\end{array}$ & ICE stop & $\begin{array}{c}\text { Airport } \\
\text { connector }\end{array}$ \\
\hline Monopoly & 523.1132 & 490.8703 & 0.2426 & 0.2417 & 0.4472 & 0.0552 \\
Duopoly & 548.7363 & 569.6048 & 0.2439 & 0.2438 & 0.6913 & 0.0328 \\
Triopoly_. & 787.4656 & 778.7168 & 0.2415 & 0.2417 & 0.834 & 0.0456 \\
Monopoly MFB & 581.8598 & 541.4207 & 0.2401 & 0.2387 & 0.3659 & 0.3548 \\
Monopoly FB & 482.8764 & 521.2876 & 0.2427 & 0.2412 & 0.6038 & 0.1887 \\
Monopoly_others & 440.0675 & 376.6779 & 0.2473 & 0.2412 & 0.4959 & 0.1157 \\
Duopoly MFB & 489.3029 & 508.4222 & 0.2462 & 0.2458 & 0.5929 & 0.0714 \\
Duopoly FB & 525.6874 & 572.9124 & 0.2485 & 0.2486 & 0.6122 & 0.051 \\
Duopoly MFB+FB & 587.9911 & 603.5104 & 0.2414 & 0.2411 & 0.7528 & 0.0144 \\
Duopoly others & 414.771 & 414.9212 & 0.248 & 0.2508 & 0.6957 & 0 \\
\hline
\end{tabular}


Table 6: OLS estimation results (November 2014)

\begin{tabular}{|c|c|c|c|c|}
\hline & $\begin{array}{c}(1) \\
\text { Price per km }\end{array}$ & $\begin{array}{c}(2) \\
\text { Price per km }\end{array}$ & $\begin{array}{c}\text { (3) } \\
\text { Price per km }\end{array}$ & $\begin{array}{c}\text { (4) } \\
\text { Price per km }\end{array}$ \\
\hline Number of providers on relation & $\begin{array}{c}-0.029^{* * *} \\
(0.001)\end{array}$ & & & \\
\hline Monopoly & & $\begin{array}{l}0.098^{* * *} \\
(0.005)\end{array}$ & & \\
\hline Duopoly & & $\begin{array}{l}0.046^{* * *} \\
(0.004)\end{array}$ & & \\
\hline Triopoly & & $\begin{array}{c}0.006 \\
(0.004)\end{array}$ & & \\
\hline Monopoly MeinFernbus & & & $\begin{array}{l}0.100^{* * *} \\
(0.004)\end{array}$ & \\
\hline Monopoly FlixBus & & & $\begin{array}{c}-0.039^{* * *} \\
(0.009)\end{array}$ & \\
\hline Monopoly others & & & $\begin{array}{l}0.169^{* * *} \\
(0.009)\end{array}$ & \\
\hline Duopoly MeinFernbus & & & & $\begin{array}{l}0.153^{* * *} \\
(0.005)\end{array}$ \\
\hline Duopoly FlixBus & & & & $\begin{array}{l}0.110^{* * *} \\
(0.008)\end{array}$ \\
\hline Duopoly MeinFernbus + FlixBus & & & & $\begin{array}{l}-0.003 \\
(0.003)\end{array}$ \\
\hline Daily Frequency & $\begin{array}{c}-0.002^{* * *} \\
(0.000)\end{array}$ & $\begin{array}{c}-0.003^{* * *} \\
(0.000)\end{array}$ & $\begin{array}{c}-0.002^{* * *} \\
(0.000)\end{array}$ & $\begin{array}{c}-0.003^{* * *} \\
(0.000)\end{array}$ \\
\hline \# of observations & 40568 & 40568 & 28688 & 34959 \\
\hline
\end{tabular}

Note: Robust standard errors in parenthesis. Not reported (though included) are the control variables shown in Table 2. Significance level: ${ }^{*} p<0.05,{ }^{* *} p<0.01,{ }^{* * *} p<0.001$ 
Table 7: Specific price determinants IV estimation results (January 2015)

\begin{tabular}{|c|c|c|c|c|}
\hline & (1) & $(2)$ & (3) & (4) \\
\hline & Price per km & Price per km & Price per km & Price per km \\
\hline Monopoly MeinFernbus & $\begin{array}{l}0.162^{* * *} \\
(0.007)\end{array}$ & $\begin{array}{l}0.166^{* * *} \\
(0.007)\end{array}$ & & \\
\hline Monopoly FlixBus & $\begin{array}{l}0.364^{* * *} \\
(0.037)\end{array}$ & $\begin{array}{l}0.374^{* * *} \\
(0.037)\end{array}$ & & \\
\hline Monopoly others & $\begin{array}{l}0.223^{* * *} \\
(0.028)\end{array}$ & $\begin{array}{l}0.227^{* * *} \\
(0.028)\end{array}$ & & \\
\hline Duopoly MeinFernbus & & & $\begin{array}{l}0.429^{* * *} \\
(0.028)\end{array}$ & $\begin{array}{l}0.446^{* * *} \\
(0.027)\end{array}$ \\
\hline Duopoly FlixBus & & & $\begin{array}{l}0.408^{* * *} \\
(0.029)\end{array}$ & $\begin{array}{l}0.407^{* * *} \\
(0.029)\end{array}$ \\
\hline Duopoly MeinFernbus + FlixBus & & & $\begin{array}{l}0.050^{* * *} \\
(0.007)\end{array}$ & $\begin{array}{l}0.052^{* * *} \\
(0.007)\end{array}$ \\
\hline Daily frequency & $\begin{array}{l}0.001^{* * *} \\
(0.000)\end{array}$ & $\begin{array}{l}0.001^{* * *} \\
(0.000)\end{array}$ & $\begin{array}{l}-0.000 \\
(0.000)\end{array}$ & $\begin{array}{c}0.000 \\
(0.000)\end{array}$ \\
\hline Calendar controls & no & yes & no & yes \\
\hline Angrist-Pischke first stage F-Test (1) & 968.56 & 973.42 & 71.77 & 71.51 \\
\hline Angrist-Pischke first stage F-Test (2) & 64.40 & 64.57 & 64.96 & 64.98 \\
\hline Angrist-Pischke first stage F-Test (3) & 83.58 & 85.34 & 585.39 & 574.54 \\
\hline $\begin{array}{l}\text { Angrist-Pischke first stage F-Test } \\
\text { (Freq.) }\end{array}$ & 313.05 & 309.70 & 400.53 & 417.47 \\
\hline Kleibergen-Paap Wald rk F-Statistic & 49.50 & 49.44 & 64.24 & 63.99 \\
\hline $\begin{array}{l}\text { Stock-Yogo weak ID test critical } \\
\text { values }(10 \%)\end{array}$ & 11.52 & 11.52 & 11.44 & 11.44 \\
\hline Test of endogeneity & 0.0000 & 0.0000 & 0.0000 & 0.0000 \\
\hline \# of observations & 36,985 & 36,985 & 36,936 & 36,936 \\
\hline
\end{tabular}

Notes: Robust standard errors in parentheses; 2-step GMM estimation is applied; All variables reported above are treated as endogenous; Instruments are terciles and quintiles, respectively, of population, fraction of people aged under 24 and available income plus dummies for airport connector and ICE rail connections in origin and destination cities; Not reported (though included) are the control variables shown in Table 2; Significance level: ${ }^{*} p<0.1,{ }^{* *} p<0.05,{ }^{* * *} p<0.01$. 